\title{
Synthesis, Spectroscopic Characterization and in Vitro Cytotoxicity Assay of Mropholine Mannich Base Derivatives of Benzimidazole with Some Heavy Metals
}

\author{
Mahasin Alias and Shaimaa R. Bakir \\ Department of Chemistry, College of Science for Women University of Baghdad, Baghdad-Iraq. \\ Corresponding Author: shamaa.ali@yahoo.com
}

\begin{abstract}
Mannich bases derivatives of Benzimidazole were prepared from condensation reaction of 2mercaptobenzimidazole with formaldeyhed once with mropholine and another with pyrazinamide to prepare $\mathrm{L}_{1}$ and $\mathrm{L}_{2}$ respectively, coordinated with three metal ions of $\mathrm{Pd}(\mathrm{II}), \mathrm{Pt}(\mathrm{IV})$ and $\mathrm{Au}(\mathrm{III})$. The structures of these compounds were confirmed by metal and elemental analyses, UV-Vis and FTIR spectroscopy, magnetic susceptibility, conductivity measurement at room temperature, ${ }^{1} \mathrm{HNMR}$ and ${ }^{13} \mathrm{CNMR}$. Experimental results showed that the ligands $\left(\mathrm{L}_{1} \& \mathrm{~L}_{2}\right)$ coordinated as bi-dentate and tridentate with metal ions respectively. Cytotoxicity of Mannich bases and their metal complexes were examined against mice cell line RAW 264.7 using MTT method .Each cell line was injected by following doses $(400,200,100$ and 50$) \mu \mathrm{g} / \mathrm{ml}$ of prepared compounds by using mice cell as a negative control and cis-platin as a positive control. The ligands and $\mathrm{Pd}(\mathrm{II}), \mathrm{Pt}(\mathrm{IV}), \mathrm{Au}(\mathrm{III})$ complexes showed good activity at various concentrations especially $\mathrm{Pd}(\mathrm{II})$ complexes of both complexes. [DOI: 10.22401/JNUS.21.3.06]
\end{abstract}

Keywords: Mannich Bases, Benzimidazole, 2-mercaptobenzamidazole, cytotoxicity, complexes.

\section{Introduction}

Benzimidazole is a heterocyclic secondary amino Benzo derivative of imidazole. [1a, b]. The imino group (-NH) present in benzimidazole shows both acidic and basic characteristics i.e. it is strongly acidic and weakly basic, therefore Benzimidazole is known to possesses both of these characteristics [1b]. Benzimidazole derivatives were successfully used to develop as Antiinflammatory, Antioxidant, Antineoplastic, Anthelmintic and Antiviral [1b,2a]. Benzimidazole and their derivatives have multiple applications in coordination chemistry such as (bioinorganic chemistry, photophysics and photochemistry) [2b]. From condensation reaction three components of Benzimidazole is very significant for the synthesis of different useful and active compounds. Mannich base is product from condensation three compounds of active hydrogen containing compound, $\mathrm{HCHO}$ and secondary amine [3a]. In recent years, the metal complexes of Mannich bases have been studied over a wide range due to the sensitivity and selectivity of the ligands towards different metal ions [3a]. The organic chelating compounds consisting amide moiety as a functional group have strong ability to form metal complexes and show a variety of biological activities such as, antifungal, anti HIV activity, antibacterial, Tuberculosis activity, antiviral, antiulcer and antihypertensive $[3 \mathrm{~b}, 4]$. In the immediate work, a new Mannich base obtained from the reaction of morpholine, formaldehyde and 2mercaptobenzimdazole and their metal ion complexes with Palladium, Platinum and gold were synthesized and characterized using different physicochemical techniques. The proposed structure of the synthesized Mannich bases is given in Scheme1. The cytotoxic activities of theses ligands and their metal ion complexes were studied in vitro against mice cell line.

\section{Material and Methods}

In this paper the chemicals were used of highest purity. Micro elemental data were measured by Euro EA 3000 elemental analyzer. Metal contents were carried out by using shimadzu atomic absorption 680 Flam spectrophotometer. Conductance data were obtained in $10^{-3} \mathrm{M}$ in DMF solution of the complexes using WTW conductometer at $25^{\circ} \mathrm{C}$. Infrared spectra were measurement using Shimadzu and perkin Elmer FT-Infrared spectrophotometer using CsI pellets. 
Absorbance in uv-Visible region was recorded in ethanol solution using uv-Vis.1800 PC Shimadzu Spectrophotometer. The ${ }^{1} \mathrm{H},{ }^{13} \mathrm{C}$ NMR of the compounds were recorded on a Fourier transform Varian spectrometer operating Bruker at $400 \mathrm{MHZ}$ employing DMSO $\mathrm{d}_{6}$ solvent and TMS as internal reference. Magnetic susceptibility measurements of the complexes were made by using Balance of Johnson Mattey catalytic system division at $25^{\circ} \mathrm{C}$. Melting point apparatus of Gallen kamp M.F.B-60 was used to measure the melting points of all prepared compounds. Optical density of each well in cell culture plates in cytotoxic assay was read by micro ELISA reader ASYS, Austria at a transmitting wave length on $620 \mathrm{~nm}$, Plates of cell culture were incubated at $37^{\circ} \mathrm{C}$ in SANYO, incubator Japan.

\section{1-Preparation of 2-(Morpholin-N-methyl) mercapto-1H-benzimidazole $\left(\mathrm{L}_{1}\right)$.}

This compound was prepared according to the literature[5] and as represented in the Scheme (1).
2-Synthesis of $\mathrm{N}-((2-(($ Morpholinomethyl) thiol)-1H-benzomidazol-yl)methyl) pyrazine-2-carboxamide $\left(\mathbf{L}_{2}\right)$.

The ligand $\left(\mathrm{L}_{2}\right)$ was synthesized by mannich condensation reaction between equal mole of 2-(Morpholin-N-methyl)mercapto-1Hbenzimidazole and pyrazinamide $\left(\mathrm{L}_{1}\right)$. The mixture was dissolved in methanol $(30 \mathrm{ml})$ in a beaker under ice-cold condition constant stirring. In the same solution, formaldehyde (0.01 mol) was added gradually and heated to reflux for ( $3 \mathrm{hrs})$, then kept overnight in the freezer. Color solid mass was obtained and it was washed, and recrystallized from ethanol (yield $70 \%$ ). It melts at $(132-134)^{\circ} \mathrm{C}$, as represented in Scheme (1).

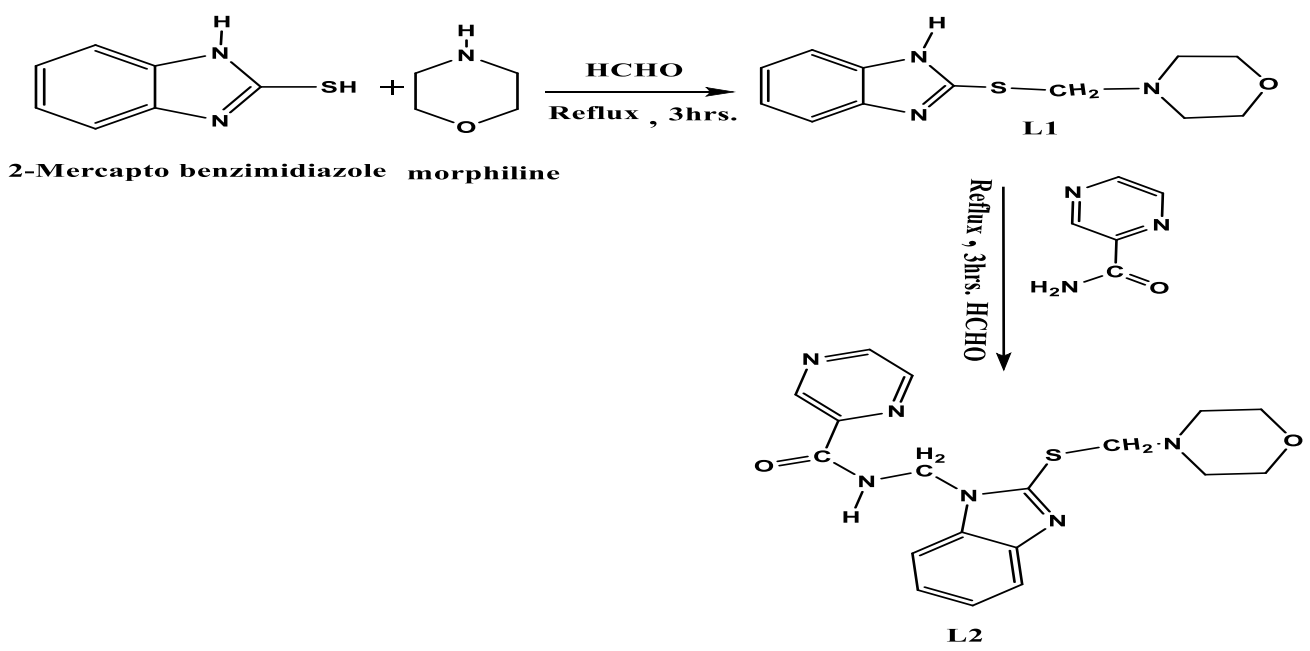

Scheme (1): General steps of the prepared $L_{1}$ and $L_{2}$.

\section{3-General Procedure to Prepare the New Complexes}

The Mannich bases reaction occurs in ethanol with metal ion salts of $\mathrm{PdCl}_{2}$, $\mathrm{H}_{2} \mathrm{PtCl}_{6} \cdot 6 \mathrm{H}_{2} \mathrm{O}$ and $\mathrm{HAuCl}_{4} \cdot 6 \mathrm{H}_{2} \mathrm{O}, 1: 2$ and $1: 1$ molar ratio for $\mathrm{L}_{1}$ and $\mathrm{L}_{2}$ respectively. The mixture was then refluxed for $(3 \mathrm{hrs}$.); the color solid complexes were formed, and then filtered, washed with ethanol and dried in dissector.
4-Formation of Metal Complexes for $\left(L_{1} \&\right.$ $L_{2}$ ) in Solution State

In solution state, Studied of the complexes formation of $\mathrm{L}_{1}$ and $\mathrm{L}_{2}$ with $\mathrm{Pd}(\mathrm{II}), \mathrm{Pt}(\mathrm{IV})$ and $\mathrm{Au}$ (III) by using ethanol as a solvent, in order to determined $\mathrm{M}$ : $\mathrm{L}$ ratio in the prepared complexes using molar ratio method [6]. A set of solutions were prepared having a various volume of ligands and constant concentration of the metal ions (0.25-3). From the 
relationship between the absorption of the absorbed light and the mole ratio of $M: L$ at $\lambda \max$ the $\mathrm{M}: \mathrm{L}$ ratio was determined.

\section{5-Cytotoxic assays}

Cytotoxicity effect of both ligands and to metal ion complexes on RAW 264.7 (mice carcinoma) was done in a sterile area using a laminar air flow cabinet biosafety, RAW 264.7 cell line was used in this study were equipped from Biotechnology Center/Al-Nahrain University. The cells were grown in Modified Eagles Medium (MEM) with 10\% fetal bovine serum, $(100 \mathrm{U} / \mathrm{ml})$ of penicillin and $(100 \mu \mathrm{g})$ of streptomycin $/ \mathrm{ml}$ in a humidified incubator with $\left(5 \% \mathrm{CO}_{2}\right)$ at $\left(37^{\circ} \mathrm{C}\right)$. The manufactured products were subjected to a screening system for evaluation of their cytotoxicity activity on mention cell line in comparison to the known anticancer drug (cis-Pt). Cell survival was further assessed by (3-(4,5- dimethylthiazol-2yl)-2,5-diphenyl tetrazolium bromide (MTT)) dye reduction assay which is based on the capability of viable cells to metabolize a yellow tetrazolium salt to violet formazan product that can be detected spectrophotometrically. Exponentially growing cells (RAW 264.7) were plated in triplicate in 96-well sterilized microtiter-plates at a density of $\left(1 \times 10^{5}\right.$ cells/well). After $24 \mathrm{hrs}$, cells were treated with decreasing doses of the compounds under investigation and incubated in $\left(5 \% \mathrm{CO}_{2}\right)$ atmosphere with high humidity. After $48 \mathrm{hrs}$ of compounds exposure, the cells were incubated with MTT $(0.5 \mathrm{mg} / 1 \mathrm{ml})$ distilled water for another $4 \mathrm{hrs}$ at $37^{\circ} \mathrm{C}$. The blue MTT formazan precipitate was then solubilized in detergent $(50 \%)$ final concentration of $\mathrm{N}, \mathrm{N}$-dimethylformamide and $10 \%$ of sodium dodecyl sulphate then incubated for an additional 2 hrs. Absorbance was measured at $620 \mathrm{~nm}$ on a multi-well ELISA plate reader [7].

\section{Results and Discussion}

Some of physical properties of the prepared compounds can be shown in Table (1), all the complexes prepared have a different color, some of them are partly soluble in most organic solvents, but other of them soluble in DMF. The results of elemental analysis ( $\mathrm{C} \quad \mathrm{H} \quad \mathrm{N}$ and $\mathrm{S}$ ) and molecular formulae are shown in Table (1). At the maximum absorption, absorbance As and Am of the solution were measured at wavelength maximum. The stability constant $\mathrm{K}$ and molar absorptivity $\varepsilon_{\max }$ have been calculated. The data of complexes formation can be listed in Table (2).

Table (1)

Shows the physical characterization, elemental analysis and metal content for all compounds.

\begin{tabular}{|c|c|c|c|c|c|c|c|c|c|}
\hline \multirow{2}{*}{ Comp. } & \multirow{2}{*}{$m \cdot p^{o} C$} & \multirow{2}{*}{ Color } & \multirow{2}{*}{$\begin{array}{l}\text { Yield } \\
\%\end{array}$} & \multicolumn{4}{|c|}{ Elemental analysis Calc. (Found) } & \multirow{2}{*}{ 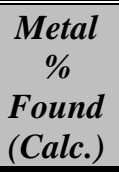 } & \multirow{2}{*}{$\mu$ s.cm ${ }^{-1}$} \\
\hline & & & & $C$ & $H$ & $N$ & $S$ & & \\
\hline $\begin{array}{c}\mathrm{C}_{12} \mathrm{H}_{15} \mathrm{~N}_{3} \mathrm{OS}\left(\mathrm{L}_{1}\right) \\
249.33\end{array}$ & $199-200$ & off white & 83 & $\begin{array}{c}57.75 \\
(56.12)\end{array}$ & $\begin{array}{c}6.01 \\
(6.679)\end{array}$ & $\begin{array}{c}16.84 \\
(17.22)\end{array}$ & $\begin{array}{c}12.83 \\
(12.98)\end{array}$ & ------ & ----- \\
\hline $\begin{array}{c}\left.\mathrm{PdL}_{2}\right] \mathrm{Cl}_{2} \cdot \mathrm{C}_{2} \mathrm{H}_{5} \mathrm{OH} \\
722.08 \\
\end{array}$ & $184-186$ & Brown & 88 & $\begin{array}{c}43.20 \\
(43.76)\end{array}$ & $\begin{array}{c}4.98 \\
(5.06)\end{array}$ & $\begin{array}{c}11.63 \\
(12.00)\end{array}$ & $\begin{array}{c}8.86 \\
(8.90)\end{array}$ & $\begin{array}{c}14.73 \\
(15.56)\end{array}$ & 72 \\
\hline $\begin{array}{c}\left.\mathrm{PtL}_{2} \mathrm{Cl}_{2}\right] \mathrm{Cl}_{2} . \mathrm{H}_{2} \mathrm{O} \\
853.66\end{array}$ & $210-212$ & Brown & 92 & $\begin{array}{c}33.73 \\
(34.17)\end{array}$ & $\begin{array}{c}3.74 \\
(3.71)\end{array}$ & $\begin{array}{c}9.83 \\
10.33)(\end{array}$ & $\begin{array}{c}7.50 \\
(8.11)\end{array}$ & $\begin{array}{c}22.84 \\
(22.92)\end{array}$ & 154 \\
\hline $\begin{array}{c}\left.\mathrm{AuL}_{2} \mathrm{Cl}_{2}\right] \mathrm{Cl} .0 .5 \mathrm{C}_{2} \mathrm{H}_{5} \mathrm{OH} \\
825.06\end{array}$ & $130-132$ & $\begin{array}{c}\text { Dark } \\
\text { brown }\end{array}$ & 77 & $\begin{array}{c}36.36 \\
(36.99)\end{array}$ & $\begin{array}{c}3.99 \\
(4.58)\end{array}$ & $\begin{array}{c}10.18 \\
(10.48)\end{array}$ & $\begin{array}{c}7.75 \\
(8.03) \\
\end{array}$ & $\begin{array}{c}23.86 \\
(24.11)\end{array}$ & 77 \\
\hline $\begin{array}{c}\mathrm{C}_{18} \mathrm{H}_{20} \mathrm{~N}_{6} \mathrm{O}_{2} \mathrm{~S}\left(\mathrm{~L}_{2}\right) \\
384.46\end{array}$ & $132-134$ & off white & 70 & $\begin{array}{c}56.18 \\
(55.81)\end{array}$ & $\begin{array}{c}5.20 \\
(5.15)\end{array}$ & $\begin{array}{c}21.84 \\
(21.06)\end{array}$ & $\begin{array}{c}8.32 \\
(8.20) \\
\end{array}$ & ----- & ---- \\
\hline $\begin{array}{c}\text { PdLCl }] \mathrm{Cl}_{1} \mathrm{C}_{2} \mathrm{H}_{5} \mathrm{OH} \\
607.88\end{array}$ & $148-150$ & $\begin{array}{l}\text { Dark } \\
\text { brown }\end{array}$ & 84 & $\begin{array}{c}39.48 \\
(39.43)\end{array}$ & $\begin{array}{c}4.27 \\
(3.72)\end{array}$ & $\begin{array}{c}13.81 \\
(14.47)\end{array}$ & $\begin{array}{c}5.26 \\
(5.78)\end{array}$ & $\begin{array}{c}17.52 \\
(16.69)\end{array}$ & 63 \\
\hline $\begin{array}{c}\left.\mathrm{PtLCl}_{3}\right] \mathrm{Cl}_{1} \mathrm{H}_{2} \mathrm{O} \\
739.46\end{array}$ & $212 d$ & $\begin{array}{l}\text { Reddish } \\
\text { orange }\end{array}$ & 88 & $\begin{array}{c}29.21 \\
(29.92)\end{array}$ & $\begin{array}{c}2.97 \\
(3.61)\end{array}$ & $\begin{array}{c}11.35 \\
(12.04)\end{array}$ & $\begin{array}{c}4.32 \\
(5.12)\end{array}$ & $\begin{array}{c}26.37 \\
(25.67)\end{array}$ & 66 \\
\hline $\begin{array}{c}\left.\mathrm{AuLCl}_{3}\right] . \mathrm{C}_{2} \mathrm{H}_{5} \mathrm{OH} \\
733.86\end{array}$ & $140-142$ & $\begin{array}{l}\text { Brownish } \\
\text { Yellow }\end{array}$ & 72 & $\begin{array}{c}32.70 \\
(33.15)\end{array}$ & $\begin{array}{c}3.54 \\
(3.98)\end{array}$ & $\begin{array}{c}11.44 \\
(11.00)\end{array}$ & $\begin{array}{c}4.36 \\
(5.21)\end{array}$ & $\begin{array}{c}26.83 \\
(27.00)\end{array}$ & 33 \\
\hline
\end{tabular}

$\mathrm{d}=$ decomposition degree 
Table (2)

Stability constant of all prepared complexes at $\left(25^{\circ} \mathrm{C}\right)$.

\begin{tabular}{|c|c|c|c|c|c|c|}
\hline Comp. & $\mathbf{A}_{\mathbf{S}}$ & $\mathbf{A}_{\mathbf{m}}$ & $\alpha$ & $\begin{array}{c}\mathcal{E}_{\max } \\
\operatorname{L.mol}^{-1} \mathrm{~cm}^{-1}\end{array}$ & $\begin{array}{c}\mathbf{K} \\
\mathbf{L} \cdot \mathrm{mol}^{-1} \\
(*): L^{2} \cdot \mathrm{mole}^{-2} \\
\end{array}$ & $\lambda_{\max (\mathrm{nm})}$ \\
\hline $\mathrm{PdL}_{1}$ & 1.129 & 1.285 & 0.121 & 12850 & $* 5.9 \times 10^{4}$ & 440 \\
\hline $\mathrm{PtL}_{1}$ & 0.333 & 0.400 & 0.167 & 4000 & $* 2.97 \times 10^{4}$ & 408 \\
\hline $\mathrm{AuL}_{1}$ & 1.200 & 1.299 & 0.076 & 12990 & $* 1.59 \times 10^{5}$ & 390 \\
\hline $\mathrm{PdL}_{2}$ & 0.221 & 0.321 & 0.311 & 3210 & $5.7 \times 10^{6}$ & 408 \\
\hline PtL $_{2}$ & 0.258 & 0.321 & 0.196 & 3210 & $2.6 \times 10^{7}$ & 384 \\
\hline $\mathrm{AuL}_{2}$ & 0.993 & 1.111 & 0.106 & 11110 & $1.86 \times 10^{9}$ & 366 \\
\hline
\end{tabular}

$\mathbf{K}=$ Stability constant

$\mathbf{A}_{\mathbf{s}}$ : Average of triplicate absorption of the solution containing a stoichometric volume of ligand and metal ion.

$\mathbf{A}_{\mathrm{m}}$ : Average of triplicate absorption of solution containing the same amount of metal and fivefold excess of ligand

\section{1-FT-IR spectra}

The bands of infrared spectra of the chelating ligands and all metal ion complexes with their Transmittance bands are given in Table (3). To diagnose the coordination sites that may be involved in coordination, the infrared spectra of these complexes were compared with those the free ligands. The infrared IR bands of $\mathrm{L}_{1}$ shown at (2931-2870), (1608) and $\left(1357 \mathrm{~cm}^{-1}\right)$ for Mannich group[8a, b], $v \mathrm{C}=\mathrm{N}$ and $v \mathrm{CN}$ respectively[8b,9a]. This band is shifted by (23-47),(27-31) and (15-17) $\mathrm{cm}^{-1}$ in the metal ion complexes respectively. Another sharp bands appeared at 1107 \& $1111 \mathrm{~cm}^{-1}$ for CNC of morpholine moiety[9b], this bands is shifted to higher and some other to lower frequency, indicate that these complexes coordinated through of the nitrogen atom from the morpholine ring for $L_{1}$ and $L_{2}$ and the nitrogen of imidazole to the central metal ion. In Infrared spectra of complexes for $\mathrm{L}_{1}$, the $v, \delta \mathrm{NH}[9 \mathrm{~b}], v \mathrm{CS}$ and $v$ CSC [10a] bands stayed at the same location of free ligands, this proves the amine and sulphur is not coordinated, as opposed to link areas for $\mathrm{L}_{1}$, the $\mathrm{L}_{2}$ coordinated with $v, \delta \mathrm{NH}, v \mathrm{CS}$ and $v$ CSC [9b,10a], the shifting of these bands stretching vibration to the lower wave number side as compared to the free ligand is indicative of participation of sulphur and $\mathrm{NH}$ group in coordination [9b,10a]. The presence of a broad band of water molecules and sharp bands of ethanol molecules in out of coordination sphere is determined by the appearance of band at (3456-3406) and (3421) $\mathrm{cm}^{-1}$ [10b], (3498, 3532) and $(3510,3521)$ $\mathrm{cm}^{-1}$ [10b] for $\mathrm{L}_{1}$ and $\mathrm{L}_{2}$ respectively, indicating the coordination of nitrogen and chloride[10a] to metal ion appeared medium and weak intensity bands $v(\mathrm{M}-\mathrm{N})$ observed near at (555-597), (559-582) $\mathrm{cm}^{-1}$ and $v(\mathrm{M}-\mathrm{Cl})$ observed at (322 and 333) and (322, 325 and 327) $\mathrm{cm}^{-1}$. The most diagnostic FT.IR bands for the ligands and their complexes in addition to other bands are shown in Table (3). 
Table (3)

IR Absorption data of ligands and their metal ion complexes.

\begin{tabular}{|c|c|c|c|c|c|c|c|c|c|c|c|c|c|c|c|}
\hline Comp. & $v \mathrm{CH}_{2}-\mathrm{N}$ & $v$ NH & $\delta$ NH & $\begin{array}{l}\mathrm{VC}=\mathrm{O} \\
\text { amide }\end{array}$ & $v \mathrm{CN}$ & $\begin{array}{c}v \\
\text { CSC }\end{array}$ & v CS & vNCS & $\begin{array}{c}v \text { CNC } \\
\text { morphline }\end{array}$ & $v \mathrm{NCN}$ & $v \mathrm{C}-\mathrm{O}-\mathrm{C}$ & $v \mathbf{C}=\mathbf{N}$ & v M-N & v M-S & others \\
\hline L1 & $\begin{array}{l}2931 \\
2870\end{array}$ & 3147 & 1438 & --- & 1357 & 1180 & 740 & $\begin{array}{l}1068 \\
1161\end{array}$ & 1107 & ---- & 1215 & 1593 & & --- & ----- \\
\hline PdL1 & $\begin{array}{l}2954 \\
2888\end{array}$ & 3155 & 1435 & ---- & 1342 & 1180 & 740 & $\begin{array}{l}1041 \\
1147\end{array}$ & 1130 & ----- & 1215 & 1624 & 570 & ---- & $\begin{array}{c}\mathrm{C}_{2} \mathrm{H}_{5} \mathrm{OH} \\
3532 \\
\text { Pd-Cl } 330\end{array}$ \\
\hline PtL1 & $\begin{array}{l}2908 \\
2823\end{array}$ & 3143 & 1433 & ---- & 1342 & 1180 & 744 & $\begin{array}{l}1037 \\
1145\end{array}$ & 1130 & ---- & 1222 & 1620 & 559 & ---- & $\begin{array}{c}v \mathrm{H}_{2} \mathrm{O} \\
3456-3406 \\
\text { Pt-Cl } 333 \\
\end{array}$ \\
\hline AuL1 & $\begin{array}{l}2951 \\
2886\end{array}$ & 3142 & 1444 & ----' & 1340 & 1188 & 744 & $\begin{array}{l}1045 \\
1149\end{array}$ & 1130 & ----- & 1220 & 1620 & 597 & ---- & $\begin{array}{c}\mathrm{C}_{2} \mathrm{H}_{5} \mathrm{OH} \\
3498 \\
\mathrm{Au}-\mathrm{Cl} 322\end{array}$ \\
\hline L2 & $\begin{array}{l}2931 \\
2866\end{array}$ & 3282 & 1462 & 1674 & 1357 & 1161 & 740 & $\begin{array}{l}1049 \\
1139\end{array}$ & 1111 & 1373 & 1215 & $\begin{array}{l}1608 \\
1581\end{array}$ & ---- & --- & --- \\
\hline PdL2 & $\begin{array}{l}2966 \\
2888\end{array}$ & 3260 & 1450 & 1675 & 1342 & 1172 & 760 & $\begin{array}{l}1061 \\
1153\end{array}$ & 1081 & 1387 & 1216 & $\begin{array}{l}1610 \\
1583\end{array}$ & 570 & 435 & $\begin{array}{c}\mathrm{vC}_{2} \mathrm{H}_{5} \mathrm{OH} \\
3521 \\
\mathrm{Pd}-\mathrm{Cl} 327 \\
\end{array}$ \\
\hline PtL2 & $\begin{array}{l}2981 \\
2888\end{array}$ & 3268 & 1450 & 1671 & 1340 & 1176 & 763 & $\begin{array}{l}1059 \\
1153\end{array}$ & 1080 & 1387 & 1216 & $\begin{array}{l}1610 \\
1583\end{array}$ & 559 & 451 & $\begin{array}{c}\mathrm{H}_{2} \mathrm{O} \\
3421 \\
\mathrm{Pt}-\mathrm{Cl} 322\end{array}$ \\
\hline AuL2 & $\begin{array}{l}2978 \\
2872\end{array}$ & 3261 & 1492 & 1678 & 1341 & 1176 & 762 & $\begin{array}{l}1061 \\
1150\end{array}$ & 1089 & 1389 & 1219 & $\begin{array}{l}1610 \\
1573\end{array}$ & 582 & 450 & $\begin{array}{c}\mathrm{vC}_{2} \mathrm{H}_{5} \mathrm{OH} \\
3510 \\
\mathrm{Au}-\mathrm{Cl} 325\end{array}$ \\
\hline
\end{tabular}

\section{2-Magnetic moments, electronic spectral data and conductivity measurements}

The spectral data of the ligands and their metal ion complexes were carried out in ethanol solution, listed in Table (4). The ligands exhibits strong absorption bands at (33003, 3587sh, 40485, 45454, and 33112, $37453,40485,45045) \mathrm{nm}$ attributed to $\mathrm{n} \rightarrow \pi^{*}$ and $\pi \rightarrow \pi^{*}$, respectively [11a]. Diagnosis geometry of the synthesized complexes depend on the UV -vis spectrum and the complexes were shown to have a square planner or octahedral geometry. The electronic spectral for metal complexes of $\mathrm{Pd}(\mathrm{II}), \mathrm{Pt}(\mathrm{VI})$ and $\mathrm{Au}(\mathrm{III})$ were studies.

$\mathrm{PdL}_{1} \& \mathrm{PdL}_{2}$ :The electronic spectra of $\mathrm{Pd}$ complexes show a broad bands at 24509, 24390, 27322 and $31250 \mathrm{~cm}^{-1}$ which attributed to ${ }^{1} \mathrm{~A}_{1} \mathrm{~g} \rightarrow{ }^{1} \mathrm{~B}_{1} \mathrm{~g}(\mathrm{v} 1)$ transition and the later one is due to ${ }^{1} \mathrm{~A}_{1} \mathrm{~g} \rightarrow{ }^{1} \mathrm{Eg}(\mathrm{v} 2)$ transitions respectively of square planer geometry [11a,11b]. Another bands appeared at 32786, 42553 and $35714,43478 \mathrm{~cm}^{-1}$ can be assigned to $\mathrm{L} \rightarrow \mathrm{Pd} \mathrm{CT}$ transitions due to charge transfer transition for $L_{1}$ and $L_{2}$ respectively [12a, b]. The measured magnetic moment is zero B.M showed that the complexes to be low spin, and the conductivity in DMF indicted that the both complexes are ionic[11a].

$\mathrm{PtL}_{1} \& \mathrm{PtL}_{2}$ :The $\mathrm{Pt}$ (IV) ion with $\mathrm{d}^{6}$ configuration and the magnetic moment equal to zero in their complexes can be suggested an octahedral geometry of theses complexes. The octahedral coordinated of $\mathrm{Pt}(\mathrm{IV})$ ion in the position $(26041,33557) \&(24390,26666) \mathrm{cm}^{-}$ ${ }^{1}$ has the ground state ${ }^{1} \mathrm{~A}_{1} \mathrm{~g}$ and excited state should be ${ }^{1} \mathrm{~T}_{1} \mathrm{~g},{ }^{1} \mathrm{~T}_{2} \mathrm{~g}$ [11a,12a], in addition to a weak bands assigned to spin forbidden, singlet -triplet transition may be observed for two prepared complexes at lower energies than the spin allowed transitions[11b,12b]. The prepared brown and reddish orange of $\mathrm{Pt}(\mathrm{IV})$ complexes showed another bands at (39215, 32362 and 47393$) \mathrm{cm}^{-1}$ which assigned to ligand $\rightarrow \mathrm{Pt}$ CT transition respectively[10a]. The conductivity measurement showed that both complexes to be ionic[12b].

$\mathrm{AuL}_{1} \& \mathrm{AuL}_{2}$ :The spectra of these complexes gave three absorption bands appeared at (27282, 36037, 25641 and 31250), (40816, 45454, 34364 and 47619) $\mathrm{cm}^{-1}$ for $\mathrm{L}_{1}$ and $\mathrm{L}_{2}$ respectively, which indicate an octahedral geometry of these complexes [11b,13a], assigned to ${ }^{3} \mathrm{~A}_{2} \mathrm{~g} \rightarrow{ }^{3} \mathrm{~T}_{2} \mathrm{~g},{ }^{3} \mathrm{~A}_{2} \mathrm{~g} \rightarrow{ }^{3} \mathrm{~T}_{1} \mathrm{~g}$, ${ }^{3} \mathrm{~A}_{2} \mathrm{~g} \rightarrow{ }^{3} \mathrm{~T}_{1} \mathrm{~g}_{(\mathrm{P})}$ and $\mathrm{L} \rightarrow \mathrm{Au} \quad \mathrm{CT}$ transition respectively $[11 b, 12 b, 13 b]$. It is possible to calculate the values of $\mathrm{Dq}$ and $B^{\prime}$ using band position of $v_{1}$ and $v_{2}$. Value of $v_{3}$ was calculated to be around 52919 and $56465 \mathrm{~cm}^{-1}$ for $\mathrm{AuL}_{1}$ and $\mathrm{AuL}_{2}$ respectively [13b]. The ratio $v_{2} / v_{1}=1.32 \& 1.21$ fits the diagram at $3.1 \& 3.5 \mathrm{Dq} / \mathrm{B}^{\prime}, \mathrm{B}^{\prime}$ will be 874.0 and $719.5,15$ for $L_{1} \& B^{\prime}=13110,10792$ for $L_{2}$. The value of the constant field splitting 10Dq will be 27094 
and $25182 \mathrm{~cm}^{-1}$ for $\mathrm{L}_{1}$ and $\mathrm{L}_{2}$ respectively; it is approximately equal to the first transition. The values are in the rang $(77 \& 33) \mu$ s. $\mathrm{cm}^{-1}$ of the complexes in DMF, this data indicate ionic and nonionic complexes for $\mathrm{AuL}_{1}$ and $\mathrm{AuL}_{2}$ respectively. Magnetic moments of two complexes are shown in Table (4).

Table (4)

Electronic spectra, conductance in DMF and magnetic moment for ligands and their metal ion Complexes.

\begin{tabular}{|c|c|c|c|c|c|c|c|c|}
\hline $\begin{array}{l}\text { Molecular } \\
\text { formula }\end{array}$ & $\mathbf{L}_{1}$ & $\mathbf{L}_{2}$ & $\operatorname{PdL}_{1}$ & PtL $_{1}$ & $\mathbf{A u L}_{1}$ & $\mathbf{P d L}_{2}$ & $\mathrm{PtL}_{2}$ & $\mathrm{AuL}_{2}$ \\
\hline $\begin{array}{l}\text { Absorption } \\
\text { Bands }\left(\mathrm{cm}^{-1}\right)\end{array}$ & $\begin{array}{c}33003,3587 \mathrm{sh} \\
40485,45454\end{array}$ & $\begin{array}{l}33112,37453 \\
40485,45045\end{array}$ & $\begin{array}{l}24509 \\
27322 \\
32786, \\
42553 \\
\end{array}$ & $\begin{array}{l}10695 \\
26041 \\
33557 \\
39215 \\
\end{array}$ & $\begin{array}{c}27282 \\
36037 \\
52919_{\text {(cal.) }} \\
40816,45454 \\
\end{array}$ & $\begin{array}{c}22727 \\
31250 \\
35714,43478\end{array}$ & $\begin{array}{c}10309 \\
24390 \\
26666 \\
32362,47393 \\
\end{array}$ & $\begin{array}{c}25641 \\
31250 \\
56465_{\text {(cal.) }} \\
34364,47619 \\
\end{array}$ \\
\hline Assignments & $\begin{array}{l}\left(\mathrm{n} \rightarrow \pi^{*}\right) \\
\left(\pi \rightarrow \pi^{*}\right)\end{array}$ & $\begin{array}{l}\left(\mathrm{n} \rightarrow \pi^{*}\right) \\
\left(\pi \rightarrow \pi^{*}\right)\end{array}$ & $\begin{array}{c}{ }^{1} \mathrm{~A}_{1} \mathrm{~g} \rightarrow{ }^{1} \mathrm{~B}_{1} \mathrm{~g} \\
{ }^{1} \mathrm{~A}_{1} \mathrm{~g} \rightarrow{ }^{1} \mathrm{Eg} \\
\mathrm{L} \rightarrow \mathrm{PdCT}\end{array}$ & $\begin{array}{c}{ }^{1} \mathrm{~A}_{1} \mathrm{~g} \rightarrow{ }^{3} \mathrm{~T}_{2} \mathrm{~g},{ }^{3} \mathrm{~T}_{1} \mathrm{~g} \\
{ }^{1} \mathrm{~A}_{1} \mathrm{~g} \rightarrow{ }^{1} \mathrm{~T}_{1} \mathrm{~g} \\
{ }^{1} \mathrm{~A}_{2} \mathrm{~g} \rightarrow{ }^{1} \mathrm{~T}_{2} \mathrm{~g} \\
\mathrm{~L} \rightarrow \mathrm{Pt} \mathrm{CT} \\
\end{array}$ & $\begin{array}{c}{ }^{3} \mathrm{~A}_{2} \mathrm{~g} \rightarrow{ }^{3} \mathrm{~T}_{2} \mathrm{~g} \\
{ }^{3} \mathrm{~A}_{2} \mathrm{~g} \rightarrow{ }^{3} \mathrm{~T}_{1} \mathrm{~g} \\
{ }^{3} \mathrm{~A}_{2} \mathrm{~g} \rightarrow{ }^{3} \mathrm{~T}_{1} \mathrm{~g}_{(\mathrm{P})} \\
\mathrm{L} \rightarrow \mathrm{Au} \mathrm{CT} \\
\end{array}$ & $\begin{array}{l}{ }^{1} \mathrm{~A}_{1} \mathrm{~g} \rightarrow{ }^{1} \mathrm{~B}_{1} \mathrm{~g} \\
{ }^{1} \mathrm{~A}_{1} \mathrm{~g} \rightarrow{ }^{1} \mathrm{Eg} \\
\mathrm{L} \rightarrow \mathrm{PdCT}\end{array}$ & $\begin{array}{c}{ }^{1} \mathrm{~A}_{1} \mathrm{~g} \rightarrow{ }^{3} \mathrm{~T}_{2} \mathrm{~g},{ }^{3} \mathrm{~T}_{1} \mathrm{~g} \\
{ }^{1} \mathrm{~A}_{1} \mathrm{~g} \rightarrow{ }^{1} \mathrm{~T}_{1} \mathrm{~g} \\
{ }^{1} \mathrm{~A}_{1} \mathrm{~g} \rightarrow{ }^{1} \mathrm{~T}_{2} \mathrm{~g} \\
\mathrm{~L} \rightarrow \mathrm{Pt} \mathrm{CT} \\
\end{array}$ & $\begin{array}{c}{ }^{3} \mathrm{~A}_{2} \mathrm{~g} \rightarrow{ }^{3} \mathrm{~T}_{2} \mathrm{~g} \\
{ }^{3} \mathrm{~A}_{2} \mathrm{~g} \rightarrow{ }^{3} \mathrm{~T}_{1} \mathrm{~g} \\
{ }^{3} \mathrm{~A}_{2} \mathrm{~g} \rightarrow{ }^{3} \mathrm{~T}_{1} \mathrm{~g}_{(\mathrm{P})} \\
\mathrm{L} \rightarrow \mathrm{Au} \mathrm{CT} \\
\end{array}$ \\
\hline $\begin{array}{c}\mu_{\text {eff }} \\
\text { B.M. }\end{array}$ & ----- & ------ & 0.00 & 0.00 & $(2.82)$ & 0.00 & 0.00 & $(2.82)$ \\
\hline $\begin{array}{l}\text { Suggested } \\
\text { structure }\end{array}$ & ----.- & ------ & Sq.P & Oh & Oh & Sq.P & $\mathrm{Oh}$ & Oh \\
\hline
\end{tabular}

\section{3-1 HNMR and ${ }^{13}$ CNMR spectra}

Mode of the ligands and Pd, Pt complexes are also provided by the ${ }^{1} \mathrm{H}-\mathrm{NMR},{ }^{13} \mathrm{CNMR}$ spectra of the Mannich bases and the diamagnetic of Pd (II) and Pt (IV) complexes, which were recorded in DMSO $\mathrm{d}_{6}$. The ${ }^{1}$ HNMR spectra of the ligands show signals of aromatic protons appeared at (7.13-7.32) \& (7.17-7.67) $\delta$ respectively[14a]. The $(\mathrm{N}-\mathrm{H})$ proton chemical shift take place at $(12.25,8.98) \delta[11 \mathrm{a}, 14 \mathrm{a}]$ which gave rise to singlet, doublet for $\mathrm{L}_{1}$ and $\mathrm{L}_{2}$ respectively. The peak at (3.90),(3.97) and (5.15) ppm are attributed to the $\mathrm{CH}_{2}-\mathrm{N}$ groups of Mannich bases present in $\mathrm{L}_{1}$ and $\mathrm{L}_{2}[14 \mathrm{~b}, 2 \mathrm{a}]$. The signals appeared in the position of $(\delta 3.57,3.59$ and $\delta 2.49,2.48)$ are due to $-\mathrm{O}-\mathrm{CH}_{2}$ and $\mathrm{N}-\mathrm{CH}_{2}$ proton of morpholine moiety for $\mathrm{L}_{1}$ and $\mathrm{L}_{2}$ respectively [14a]. Other bands appeared at $\delta(8.86,9.29$ and 9.99) are due to pyrazine proton for $\mathrm{L}_{2}$ ligand [15a].

In Pd (II) and Pt(IV) complexes, the (d, N$\mathrm{H})$ proton shifted down field to $9.00 \delta$, evidence the coordination of $\mathrm{NH}$ moiety to Palladium and Platinum ion in $\mathrm{L}_{2}[15 \mathrm{~b}]$. The signal due to morpholine $\mathrm{N}-\mathrm{CH}_{2}$ protons is also shifted slightly downfield and appeared at $2.69 \& 2.68 \delta$ in the complexes $\mathrm{L}_{1}$ and $\mathrm{L}_{2}$. This is indication to the coordination of nitrogen for morpholine [14a].
In the ${ }^{13} \mathrm{C}-\mathrm{NMR}$ spectra of the ligands $\mathrm{L}_{1}$ and $\mathrm{L}_{2}$, the signals in the range from (47.96, $68.78) \&(48.01,68.99) \mathrm{ppm}$ were assigned to carbon atoms of morpholine $\left(\mathrm{N}-\mathrm{CH}_{2}, \mathrm{OCH}_{2}\right)$ [14a]. Aromatic ring carbon atoms of benzimidazole were determined in the range of 114.05-138.92 and 114.08-139.58 ppm respectively [10a,14a]. Additional signals were determined at 61.0, 60.64, 61.64ppm and $147.01,151.34 \mathrm{ppm}$ [14b], which are assigned to the carbon atom of $\mathrm{CH}_{2}-\mathrm{N}$ of Mannich bases and $(\mathrm{NCN})$ for benzimidazole for $\mathrm{L}_{1} \& \mathrm{~L}_{2}$ respectively [16]. Other bands are shown in Table (5). 
Table (5)

${ }^{13}$ CNMR,${ }^{1} \mathrm{HNMR}$ spectral of $L_{1}$ and $L_{2}$ and $\mathrm{Pd}(\mathrm{II}), \mathrm{Pt}(\mathrm{IV})$ complexes.

\begin{tabular}{|c|c|}
\hline${ }^{13} \mathrm{CNMR}$ & ${ }^{1} \mathrm{HNMR}$ \\
\hline $\begin{array}{l}\left(\mathrm{DMSO}-\mathrm{d}_{6}\right) \text { ppm: } \mathrm{L}_{1}: 114.05-138.29(4 \mathrm{C}- \\
6,68.78\left(\mathrm{~N}-\mathrm{CH}_{2}, \mathrm{O}-\mathrm{CH}_{2}\right), 61.0\left(\mathrm{CH}_{2}-\mathrm{N}\right) \text {, } \\
\text { J-C=N-), }\end{array}$ & $\begin{array}{l}\text { DMSO } \mathrm{d}_{6}, \mathrm{ppm} \quad \delta \mathrm{L}_{1}: \quad 7.13-7.32 \quad(\mathrm{~m}, 4 \mathrm{H}, \mathrm{Ar}), \\
2.49\left(\mathrm{t}, 4 \mathrm{H}, \mathrm{CH}_{2}\right), 3.57\left(\mathrm{t}, 4 \mathrm{H}, \mathrm{CH}_{2}\right), 3.90\left(\mathrm{~S}, 2 \mathrm{H}, \mathrm{CH}_{2}\right), \\
12.25(\mathrm{~S}, 1 \mathrm{H}, \mathrm{NH}) .\end{array}$ \\
\hline $\begin{array}{l}{ }^{13} \mathrm{CNMR}\left(\mathrm{DMSO}-\mathrm{d}_{6}\right) \delta \mathrm{L} 2: 114.08-139.58(4 \mathrm{C}-\mathrm{Ar}), \\
48.01,68.99\left(\mathrm{~N}-\mathrm{CH}_{2}, \mathrm{O}-\mathrm{CH}_{2}\right), 60.6461 .64\left(\mathrm{CH}_{2^{-}}\right. \\
\mathrm{N}), 151.34(\mathrm{~N}-\mathrm{C}=\mathrm{N}-), 172.07(-\mathrm{C}=\mathrm{O}), 145.56(\mathrm{C}- \\
\mathrm{C}=\mathrm{O} \text { pyr. }), 144.94,145.01,146.47(\mathrm{C}-\mathrm{Pyr} . r i n g) .\end{array}$ & $\begin{array}{l}\text { DMSO } \mathrm{d}_{6}, \delta \quad \mathrm{L}_{2}: \quad 7.17-7.67(\mathrm{~m}, 4 \mathrm{H}, \mathrm{Ar}), 2.48 \\
\left(\mathrm{t}, 4 \mathrm{H}, \mathrm{CH}_{2}\right), 3.59\left(\mathrm{t}, 4 \mathrm{H}, \mathrm{CH}_{2}\right), 3.97\left(\mathrm{~S}, 2 \mathrm{H}, \mathrm{S}-\mathrm{CH}_{2}\right), \\
\text { 5.15(d,2H,N-CH2), 8.89(t,1H,NH), 8.88, } 9.29, \\
9.99(\mathrm{~d}, 3 \mathrm{H}, \mathrm{CH}-\mathrm{Npyr})\end{array}$ \\
\hline
\end{tabular}

Accordingly, the proposed structure model for these newly complexes prepared which is characterized by physical and spectroscopic analysis can be shown in following figure:

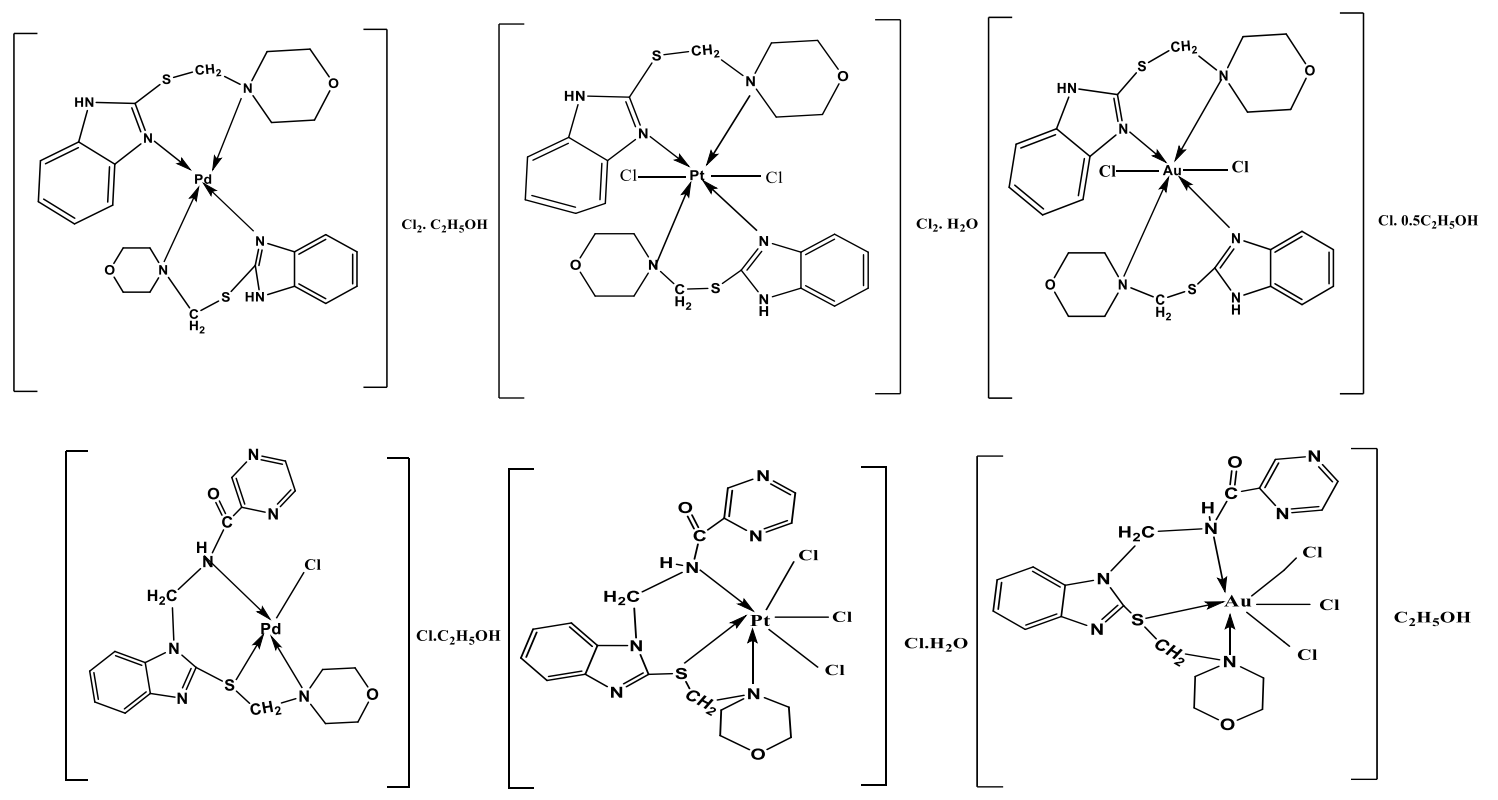

Fig(1): Suggested Structures of Prepared Complexes.

\section{4-In vitro cytotoxicity}

Cancer and some malignant diseases occur as a result of several factors, such as DNA damage, oxidative stress and chronic inflammation. These diseases can be controlled by resistant to carcinogens and or to inhibit advancement of the disease by chemotherapy [17a]. The newly synthesized products were evaluated for their in vitro cytotoxic activity against RAW 264.7 cell line. Our results showed that all of the newly synthesized products especially metal ion complexes exhibited a strong growth inhibition activity on the tested cell line in comparison to the reference anticancer drug i.e (cis-Pt). Benzimidazole is an important pharmacophore and a privileged structure in medicinal chemistry. Nowadays is a moiety of choice which possesses many pharmacological properties [17b], in $\mathrm{L}_{1}$ complexes the activity of these complexes also comes from presence of morpholine moiety beside the benzimidazole group because it is considered an important building blocks in the field of medicinal chemistry especially as anticancer drugs in vivo \& in vitro [18a]. In the $\mathrm{L}_{2}$ the presence of pyrazine group, which possessed a wide range of biological activities being found in nature and in many drugs [18b], and due to the importance of pyrazine nucleus in drug discovery and according to continuous searches of new potent and safe anticancer agents we were attempted to test compounds contain of this moiety against cancer cell line 
and good results were obtained for this group i.e in $\mathrm{L}_{2}$ compare to $\mathrm{L}_{1}$ complexes. From the research results, some factors are responsible for the pharmacological efficacy of these compounds (ligands and complexes) such as size of metal, polarity, charge distribution, ionic character and geometry shape. The results exhibited the higher inhibition rate of $\mathrm{Pd}(\mathrm{II})$ complexes of both ligands compare to $\mathrm{Au}(\mathrm{III})$ \& $\mathrm{Pt}(\mathrm{IV})$ complexes and this may be due to square planner geometry of these complexes which is preferred to cell than the octahedral geometry. Many of the prepared Pd (II) complexes showed a special antitumor activity in vitro compared to the $\mathrm{pt}(\mathrm{IV})$ complexes due to the fact that these compounds are effective (high lability) in biological fluids. The mechanism of these complexes appears based on effects on DNA [19]. Octahedral Platium(IV) complexes have a capability towards ligands substitution by a dissociative mechanism versus an associative mechanism for Platinum (II), We conclude from this result, $\mathrm{Pt}(\mathrm{IV})$ compounds are relatively more inert. This is favored for oral bioavailability and lower toxicity, but it is undesirable for DNA interpolation in vitro. In spite of that, several Platinum (IV) complexes are showing considerable activity in initial trials, with functionality thought to depend on the in vivo reduction of $\mathrm{Pt}(\mathrm{IV})$ to $\mathrm{Pt}(\mathrm{II})$, producing reactive intermediates capable of interacting with DNA. (The reduction of $\mathrm{Pt}(\mathrm{IV})$ to $\mathrm{Pt}(\mathrm{II})$ compounds by biological agents is necessary to exert their antitumor activity). The reduction potential of $\mathrm{Pt}$ (IV) complexes depends on the type of equatorial and axial ligands [19,20]. Gold complexes have shown great efficacy as an anticancer drug, due to the fact that many $\mathrm{Au}(\mathrm{I})$ and $\mathrm{Au}$ (III) compounds inhibit the growth of cancer cells, The cytotoxic effects of these complexes are associated with DNA damage and mitochondrial function inhibition, and their interaction with many intracellular targets such as cysteine, nitrogen bases, glutathione reductase, thioredoxin reductase and selenocysteine [21a,b]. The gold (III) complex have octahedral geometry and high charge of gold (III) may be reduced inside the cell into low charge gold(I) and make more stable complex which may be due to increasing the inhibition rates on RAW. 264.7 cell line. The In vitro cytotoxicity results are summarized in Table (6) and Fig.(2).

Table (6)

Shows the percentage inhibition rate on (RAW. 264.7).

\begin{tabular}{||c||c||c||c|c||}
\hline \multirow{2}{*}{ Compounds } & \multicolumn{4}{|c||}{ Inhibition rate \% } \\
\cline { 2 - 5 } & $\mathbf{4 0 0} \boldsymbol{\mu g} / \mathbf{m l}$ & $\mathbf{2 0 0} \boldsymbol{\mu g} / \mathbf{m l}$ & $\mathbf{1 0 0} \boldsymbol{\mu g} / \mathbf{m l}$ & $\mathbf{5 0} \boldsymbol{\mu g} / \mathbf{m l}$ \\
\hline \hline Cis-Pt & 76.37 & 72.78 & 67.88 & 63.67 \\
\hline $\mathbf{L}_{\mathbf{1}}$ & 62.50 & 57.50 & 56.00 & 47.75 \\
\hline PtL $_{\mathbf{1}}$ & 79.75 & 76.00 & 73.50 & 69.00 \\
\hline PdL $_{\mathbf{1}}$ & 78.00 & 73.25 & 71.25 & 71.00 \\
\hline \hline AuL $_{\mathbf{1}}$ & 80.00 & 67.75 & 64.00 & 62.50 \\
\hline \hline $\mathbf{L}_{2}$ & 70.75 & 69.25 & 68.75 & 65.50 \\
\hline \hline PtL $_{2}$ & 74.66 & 73.58 & 68.75 & 64.30 \\
\hline \hline PdL $_{2}$ & 78.41 & 76.50 & 74.58 & 73.15 \\
\hline \hline AuL $_{2}$ & 77.47 & 75.13 & 72.75 & 68.99 \\
\hline
\end{tabular}




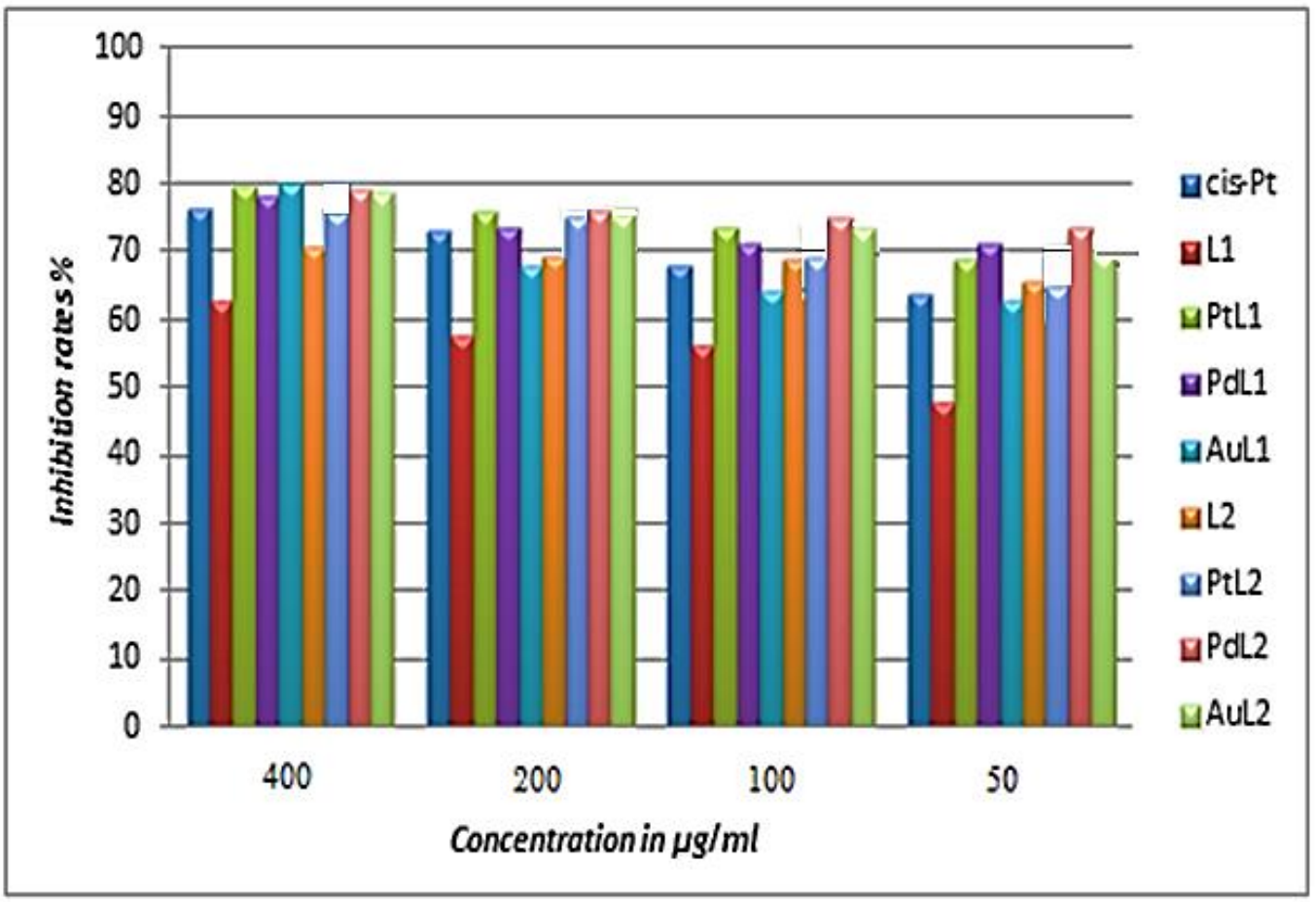

Fig.(2): Shows the percentage inhibition rate on (RAW. 264.7) after time of exposure 48 hrs.

\section{Conclusions}

The structures of the prepared compounds were suggested according to physical and spectral analysis. All data revealed that the ligands acted as bidentate and tridentate for $\mathrm{L}_{1}, \mathrm{~L}_{2}$ respectively. Based on the electronic spectral data and the magnetic susceptibility measurements, the complexes exhibited square planner geometry of palladium ion and octahedral geometry of platinum and gold ions complexes. The ligands and the metal ion complexes were screened for their cytotoxic activities. The cytotoxic studies showed that the palladium ion complexes of both ligands more active than the other compounds.

\section{References}

[1a] Preston, P. N. "Benzimidazole and Congeneric Tricyclic Compounds", Part-2; Wiley: New York, NY, USA, 531-543, 1980.

[b]-Pranika, K. and Dr. Wakode, S. R; "Antimicrobial Properties of Benzimidazole and Mannich Bases of Benzimidazole": A Review, (IJSR), 5 (3), 762-772, 2016.

[2a] Misbah, U. R.; Muhammad A.; Muhammad, I. and Muhammad, F. "Synthesis, Characterization and Antimicrobial Properties of Mannich Base
Cyclization Derivatives of Benzimidazole and Their Metal Complexes", American J. of Chemistry 4(1): 10-21, 2014.

[b] Jeshma, K.; Burri, N.; Ahmed, K.; and Ajay K. S., "An Efficient Synthesis of 2Substituted Benzimidazoles via Photocatalytic Condensation of $o$ Phenylenediamines and Aldehydes", American Che. Soc.(ACS) Comb. Sci., 18 (10), 644-650, 2016.

[3a] Ritchu S.; Sandeep, A.; Neelam, J.; and Sandeep, J.; "Mannich Bases of 2Substituted Benzimidazoles" - A Review Journal of Pharmaceutical Technology, Research and Management 3(2), 97-111, 2015.

[b] Paul, J. M.; and Paulraj, A.; "Synthesis and Characterization of New Mannich Base of 1-[(2-Hydroxy-Phenyl)-Phenyl Amino-Methyl]-Pyrrole-2-5- dione (L) with some Transition Metal Complexes", Int.J. ChemTech Res., 9(2), 176-181, 2016.

[4] Durosinmi, L. M.; Oluduro, A. O. and Oseni, M.; "Synthesis, Characterization and Antimicrobial Properties of Benzimidazole Derivatives and Their Metal Complexes". IOSR Journal of Applied Chemistry (IOSR-JAC), 10(8), 24-45, 2017. 
[5] Mohammed, R. A.; Shetha, F. N. and Amaal, S. S.; "The Preparation of some New Mannich and Shiff bases derived from 2-Mercaptobenzimidazole", Baghdad Science J. 12(3), 516-526, 2015.

[6] Skooge, D.A.; West, D M. and James H. F.; "Fundementals of analytical chemistry", 9 $9^{\text {th }}$ Ed., Brooks \Cole, 2014.

[7] Freshney, R.I.; "Culture of Animal Cells: A manual for Basic Technique and Specialized Applications", $7^{\text {th }}$ Ed. WileyBlackwell, New York, 2016.

[8a] Nakomato, N., "Infrared and Raman Spectra of Inorganic and Coordination Compounds". $6^{\text {th }}$. ed., John Wiley and Sons, Inc., New Jersey, 2009.

[b] Enas, M. Z.; "Preparation and Spectroscopic Study of $\mathrm{Cr}(\mathrm{III}), \mathrm{Fe}(\mathrm{III})$, $\mathrm{Ni}(\mathrm{II})$ and $\mathrm{Cu}$ (II) Complexes with New Mannich Bases Derived from 3-methyl-5(4`-nitrophenyl)-2-(8-hydroxy quinolinol5-yl)", Al- Mustansiriyah J. Sci. 25( 2), 89102, 2014.

[9a] Srikanth, G.;Rajesh B.Y.; Vijayabhaskara, R. G. and Madhavi, L. B.; "Symmetrical Couplingof 2-Mercapto Benzimidazole Derivativesand Their Antimicrobial Activity", Int J Pharm Sci, 3(2), 217-220, 2011.

[b] Hammam, A. M.; EL-Gahami, M. A.; Khafagi, Z. A.; AL-Salimi, M. S.; and Ibrahim, S. A. "Synthesis and Characterization of Some New Antimicrobial Transition Metal Complexes with 1，2，4-Traizole-3-thione Schiff Bases", J. Mater. Environ. Sci. 6 (6) 15961605, 2015.

[10a] Mahasin, F. A. and Doaa, H. M.; "Synthesis, Structural Diagnosis, Theoretical Treatment and Antibacterial Study of Pd(II), Rh(III), Pt(IV) and $\mathrm{Au}(\mathrm{III})$ Complexes Containing 2-(PNitroBenzoyl) ThioBenzimidazole", (IJSR), 6.14, 14691476, 2013.

[b] Carolin, S.H.; Mahasin, F. A.; "Synthesis, spectroscopic study of Pt (IV), Au (III), $\mathrm{Rh}(\mathrm{III}), \mathrm{Co}(\mathrm{II})$ and V (IV) complexes with sodium [5-(p-nitro phenyl) -/4-phenyl1,2,4-triazole-3-dithiocarbamato

hydrazide] and cytotoxicity assay on rhabdomyosarcoma cell line of heavy metals", Baghdad Science J. Vol.9(4),668679, 2012.

[11a] Shaimaa R. Bakir, "Synthesis, Spectral Studies, and Theoretical Treatment of some New Metal Complexes with Tridentate Ligand (Schiff and Mannich Base)", Baghdad Science Journal Vol.13(2), 340-351, 2016.

[b] Figgis, B. and Hitchman, M. A. "Ligand Field Theory and Its Application", Wiley$\mathrm{VCH}$, New York, Singapore, Toronto, 2000.

[12a] Lever, A.B.P. and Solomon, E.I.; "Inorganic Electronic Structure and Spectroscopy: Applications and Case of Studies", Vol. II, John Wiley and Sons. Inc, New York, Chester, Singapore, Toronto, 2006.

[b] Mahasin, F. A.; Basha'ar A. S.; and Farah S. J.; "Coordination of Some Heavy Transition Metals Complexes with 2amino Acetic Acid-6-Methoxy Benzothiazole Using Microwave and Thermal Methods" Int J Pharm; 6(1) 6-13, 2016.

[13a] Catherine, E., H. and Alan, G. S.; "Inorganic Chemistry" $4^{\text {th }} \mathrm{Ed}$, United Kingdom, Saffron House,London, 2012.

[b] Al-Hasani, R., A.M.; Al-Abodi, A.K. and Kadem, S. A.; "Synthesis, Structural Study and Antibacterial Activity of $\mathrm{Pd}(\mathrm{II})$, $\mathrm{Ru}(\mathrm{III}), \quad \mathrm{Rh}(\mathrm{III}), \quad \mathrm{Au}(\mathrm{III})$ and $\mathrm{Pt}(\mathrm{IV})$ Complexes of 4-nitro-3\{[4- (4Hydroxyphenyl)-2-Methyl-5-Oxo-4,5-

Dihydro-1himidazol-1-YL]imino $\}-1,3-$

Dihydro-2H- Indol-2-One", J.1 of AlNahrain University.12 (2) 35-45, 2009.

[14a] Muruganandam,L.; and Kanimozhi, V. A.; "New Mannich Base Derived by Three Component Condensation of Benzamide, Benzaldehdye and Morpholine: Synthesis, Coordination Mode and Biological Activities of VOIV, MnII and FeII Metal Chelates", International J. of Chem Tech Res., 9(01), 23-29, 2016.

[b] Nurg"un, B.U.and Salih, O.; "Synthesis and characterization of $\mathrm{Ni}$ (II) and $\mathrm{Cu}$ (II) complexes derived from novel phenolic Mannich bases", Turk J Chem, 37: 101110, 2013.

[15a] Hareesh, H.N; Nagananda, G.S; Minchitha, K.U; Swetha, S; Ganai, S.A; 
Dhananjaya, B.L; Nagaraju, N; and Kathyayini, N; "Synthesis, Free Radical Scavenging Activity, Antimicrobial And Molecular Docking Studies of Novel Pyrazine 2-Carboxylic Acid Derivatives of Piperazines", RJPBCS 6(4) 1914-1926, 2015.

[b] Shanmugapriya, M.; Rizwan, S, A.; Abdul, J. A. and Syed, A.P. M.; "Synthesis of Cobalt (II), Nickel(II), Copper(II) and Zinc(II) Complexes of N-(1Morpholinosalicylyl)benzohydrazide and their Antimicrobial Activities", J. Environ. Nanotechnol., 3(2),188-193, 2014.

[16] Pratapsinha, G.; Mahadev, G.; Amarsinha, G.; Vilas, I., "Synthesis of antimicrobial active benzimidazole-2thioate derivatives of 2mercaptobenzimidazole", World J Pharm Sci 4(11), 160-164, 2016.

[17a] Anjana B.; Saroj A.; Avinash N.; Bikram S. and Ahuja, P S; "Evaluation of in vitro antimutagenic activity of seabuckthorn (Hippophae rhamnoides Linn) in Ames assay", J. Chin. Clin. Med., 2(8), 428-434, 2007.

[b] Barker HA, Smyth RD, Weissbach H, Toohey JI, Ladd JN and Volcani BE. "Isolation and properties of crystalline cobamide coenzymes containing Benzimidazole or 5,6Dimethylbenzimidazole. Journal of Biological Chemistry"; 235(2),480- 488, 1960.

[18a] Zhou, G., Zorn, N., Ting, P., Aslanian, R., Lin M., Cook John. "Development of Novel benzo morpholine class of diacylglycerol acyltransferase inhibitors". Med. Chem. Lett; 5(5): 544-549, 2014.

[b] Lucia S.; Klara K.; Pavla P.; Vladimir K.; Jiri K.; Lucie N.; Jan M.; Lieve N.; Matus P.; Katarina K.; Martin D.; and Jan Z.; "Synthesis and Biological Evaluation of $\mathrm{N}$ Alkyl-3-(alkylamino)- pyrazine-2carboxamides" Molecules 20, 8687-8711, 2015.

[19] Ismail W.;Ala'a F. E.; Mohammed A. AlNuri; Ahmad I. H.; Mohamed A.; Ahmad Abu-Obaid; Nabil Al-Zaqri; Taibi Ben Hadda and Belkheir H.; "Metal ions as Antitumor Complexes"-Review, J. Mater. Environ. Sci. 4 (4) 542-557, 2013.
[20] Łakomska I.; Wojtczak A.; Sitkowski J.; Kozerski L.; Szłyk E.; "Platinum(IV) complexes with purine analogs Studies of molecular structure and antiproliferative activity in vitro" Polyhedron, 27, 2765, 2008.

[21a] Lessa, J. A.; Guerra, J. C.; De Miranda, L. F.; Romeiro, C.F.D.; Da Silva, J.G.; Mendes, I. C.; Speziali, N. L.; SouzaFagundes, E. M.; Beraldo, H. a- Galanski M.and Keppler B., "Gold (I) Complexes with thiosemicarbazone cytotoxic agent human tumor cell line and inhibition of thioredoxin reductase activity" J. Inorg. Biochem., 105, 1729-1739, 2011.

[b] Liang,S.; HuashengC.; Zonglei Z.; QianY.; Haibo,T.; Aihua, X. and Cunde, $\mathrm{W}$.; "Synthesis and cancer cell cytotoxicity of water-soluble gold(III) substituted tetraarylporphyrin, J. of Inorganic Biochemistry”. 10847-52, 2012. 